\title{
On the Nature of Interaction in SLA: A Philosophical Stream
}

\author{
Parviz Maftoon $^{1} \&$ Nima Shakouri ${ }^{2}$ \\ ${ }^{1}$ College of Foreign Languages and Literature, Science and Research Branch, Islamic Azad University, Tehran, \\ Iran \\ ${ }^{2}$ Roudbar Branch, Islamic Azad University, Rasht, Iran \\ Correspondence: Nima Shakouri, Roudbar Branch, Islamic Azad University, Rasht, Iran. E-mail: \\ shakouri.ni@gmail.com
}

Received: February 28, 2013 Accepted: June 19, 2013 Online Published: August 15, 2013

doi:10.5539/elt.v6n9p120 URL: http://dx.doi.org/10.5539/elt.v6n9p120

\begin{abstract}
Researchers have long grappled with situating the stance of interaction in SLA, but it is only recently that interaction has begun to receive consideration from SLA quarters. Delving into the nature of interaction and the prerequisite of interaction in real world, in general, and in classroom, in particular, the authors hold that based on different perspectives of interaction, interaction can be placed into diverse philosophical stances and has a prominent role in second language classrooms. To the present writers, provided that second language teachers have good grasp of the philosophy of interaction, its pedagogical implications in the class will be more purposeful.
\end{abstract}

Keywords: ecology, affordance, interaction, dialectical, context, utterance

\section{Introduction}

Disagreement among SLA scholars may relate to how they conceive language and language learning. However, divergent epistemic commitments and paradigmatic orientations of SLA researchers is another reason for this disagreement. Hence, Yazan (2012) believes that understanding this epistemic and paradigmatic divergence, as two philosophical orientations underpinning SLA research, helps better and thorough understanding of research methods applying in EFL classrooms. Furthermore, the tension between the two principal ontological orientations, namely positivism and relativism, exerts a powerful influence on the debate between cognitive and socio-cultural approaches to SLA. As Lafford, (2007, cited in Yazan, 2012) puts forth, positivists have influenced traditional cognitivism in which individuals' mind is responsible for language acquisition, while socio-cultural approach being combined with relativist orientation conceives learning as essentially a social activity. Accordingly, meaning is co-constructed rather than discovered by those who get involved in the process of interaction.

Also, the tension between interactionist and innatist perspectives towards SLA is conspicuous. SLA theories in SLA can be considered as either nature- or nurture-based. Nature theories claim that knowledge is genetically transmitted and is innate. In fact, language acquisition is part and parcel of the genetic make-up of human beings. Although nature theories do not deny the importance of environmental stimuli, they kept its importance to minimum. Meanwhile, innatists believe that human beings are born with a built-in device which predisposes us to acquire language; this language acquisition device is a human language learning system. Nurture theories, in contrast, claim knowledge comes from experience, from our interaction with the environment through reasoning or senses. Accordingly, learning is the result of interaction with others (Long, 1981). However, as to Yazan (2012), interactionism, in sharp contrast with innatism, takes into consideration the importance of both nature and nurture in the language acquisition process. In a similar vein, Larsen-Freeman (1991), in support of interactionist views, asserts "they [interactionists] invoke both innate and environmental factors to explain language learning" (p. 266).

The idea that comprehensible input is necessary for the second language acquisition forms the basic tenet of the interactionist position; however, to Long (1981), input is necessary but not sufficient. Interactionists view the communicative give and take of natural conversations between speakers as the crucial element of the language acquisition process (Long, 1981).

Also, as to Bakhtin (1981), the only way to know ourselves is to know others and have interaction with them. In 
other words, it is only by entering into dialogue with "a diversified array of others" (Emerson, 1997, cited in Hall, Vitanova, \& Marchenkova, 2005, p.4) who are different from us we can flourish. What is implicit in Bakhtin' approach is that his dialogic heteroglossia is based on interaction, interaction between internal and external forces, between utterances and voices, between individual's self and voices of others. In a nutshell, the paper laying emphasis on the importance of interaction pursues a discussion in order to consolidate the nature of interaction in SLA and equip would-be teachers with the implementations of interaction in EFL classes.

\section{On the Necessity of Output in SLA}

Interactionists hold that interaction must consist of comprehensible input (Krashen, 1981) which allows the message to be understood, as well as output (Swain, 1995) which provides opportunities for expression and negotiation of meaning. In effect, the expression and negotiation of meaning happens when learners are given the chance to interact. Along the same vein, Lightbrown and Spada (1999) assert when learners are given the opportunity to engage in meaningful activities, they are compelled to negotiate the meaning to express and clarify their intentions, thoughts, and opinions in a way which permits them to arrive at a mutual understanding. Arriving at mutual understanding occurs when learners are working together to accomplish a particular goal. It is a truism that input and output processing have a bilateral relationship with each other; that is, when meaning is negotiated through output processing, input comprehensibility is usually increased, and learners tend to focus on salient linguistic features (Long, 1981).

Output as the corpus of utterances that learners actually produce orally and in writing has three possible functions (Swain, 1995): (1) the noticing function, (2) the hypothesis-testing function, and (3) the metalinguistic function. The noticing function relates to the possibility that when learners try to communicate, they may encounter a linguistic problem and become aware of what they do not know. Such an encounter elevates learners' awareness leading to better action on it. The hypothesis-testing function of output relates to the possibility that when learners are using their still-developing target language, they may experiment what works and what does not. For example, when learners, developing their own interlanguage, receive negative feedback, they will try to build a new hypothesis about. Metalinguistic function of output relates to the possibility that learners may be consciously thinking about language and its system; this function will help them to produce utterances that are linguistically correct and communicatively appropriate (Kumaravadivelu, 2006).

Nevertheless, some scholars including VanPatten (2004) are in disfavor with Swain's (1995) findings. VanPatten claims "output promotes acquisition but does not appear to be necessary" (p. 41). In fact, he argues that the role of pushed output is similar to any focus-on-form technique that speeds up acquisition. Put similarly, Izumi (2002, cited in VanPatten, 2004, p. 41) asserts "output can induce the learners to process the input effectively for their greater interlanguage development". Inspired by the work of Pienemann (1998), Mackey (1999) has also concluded that output is constrained by learnability issues. Put another way, output can only have an effect when learners are about to acquire a structure in the normal sequence of development. Probably, claiming that interaction will lose its discourse complexity and naturality when dressed up as a part of a lesson has become a reason for several scholars to give priority to input rather than output. In effect, the scholars (e.g., Krashen, 1981) rest on a premise that for SLA to be fostered, the interaction in the classroom must resemble, as much as possible, natural conversation.

Yet, resting on a more comprehensive perspective involves not looking at language acquisition from the so-called Cartisean-dualistic lens. From dualist perspective, mind and body are two real entities; neither of them can assimilate to the other. In the same line, language acquisition, dualistically speaking, should be considered either individual or social. Nevertheless, Bakhtin (1981), claiming that communication is the objectification of interaction, takes a dualist-materialist perspective towards language. Inclined towards the work of Bakhtin, Vološinov (1986) declares that there exists "certain dualism between the inner and the outer elements and the explicit primacy of the former, since each act of objectification [utterance] goes from inside out" (p.84). To Bakhtin (1981), this objectification is manifested in communication through materialization of interaction.

Interactionist theorists employing cognitivists' tenets apply Vygotsky's (1962) socio-cultural theory of human mental processing to define the role of interaction in SLA (Lightbrown \& Spada, 1999) and hypothesize that second language learners gain proficiency when they interact with more advanced speakers of the language, for example, teachers and peers. Scaffolding structures such as modeling, repetition, and linguistic simplification used by more proficient speakers provide support to learners, thus enabling them to function within their zones of proximal development (ZPD) (Vygotsky, 1962).

Vygotsky's socio-cultural theory is a powerful theory which believes human mind has a social origin. Henceforth, emphasizing the social origin of mind, Newman, Griffin, and Cole (1989) state that socio-cultural theory is not 
only about "the mind nor just about the externally specifiable stimulus-response relations. It is about the dialectic between the inter- and the intra-psychological and the transformations of one into another" (p. 60). That is, in the cultural development of a child, any function has two planes and appears twice: first on a social plane as a relationship between people (interpsychological category) and second on a psychological plane within the child (intrapsychological category) (Vygotsky, 1981 cited in Jordan 2004).

\section{Nature of Interaction}

Considering interaction as an interpersonal and intrapersonal phenomenon, Ellis (1999) defines interaction as "the social behavior that occurs when one person communicates with another" (p. 1). Also, in line with the work of Vygotsky (1962), Ellis (1999) contends that interaction can occur inside our mind. Put differently, this is what called private speech. In much the same way, it is held that different modules of the mind interact to construct an understanding of or a response to some phenomena (Ellis, 1999).

Inspired by the work of Halliday's (1994) metafunctions, Kumaravadivelu (2006) outlines three dimensions of interactions: (1) interaction as a textual activity, (2) interaction as an interpersonal activity, and (3) interaction as an ideational perspective. Interaction as a textual activity refers to the modification of one's speech phonologically, morphologically, lexically, and syntactically in order to maximize chances of mutual understanding and minimize instances of communication breakdown. Interaction as an interpersonal activity considers interaction as a social practice that shapes and reshapes language learning, and interaction as an ideational perspective is concerned with the fact that language can be used to conceptualize the world. In other words, the linguistic forms can represent our experience.

Long (1981), an impressive interactionist figure in SLA, is among the first to make a distinction between modified input and modified interaction. The former refers to the modification of language input, while the latter refers to the modification of conversational structures. To Long, as Kumaravadivlu (2006) reports, the importance of modified input is undeniable, but participation in meaningful interaction is made possible through modified interaction. Accordingly, Long (1981) suggests a two-part hypothesis: (1) interactional modifications geared to solving communications difficulties help to make input comprehensible, and (2) comprehensible input promotes L2 development. Studies on interaction as a textual activity show that interactional modifications help learners become aware of form-meaning relationships. In other words, internalization of target language data is the result of learners' interactional effort to make a relationship between form and meaning. Also, interactional modifications provide opportunities for further L2 development by stretching the learners' linguistic repertoire.

\section{Ecological Perspective on Interaction}

The ecological perspective of language, in general, and affordance, in particular, has earlier been proposed by Gibson (1971) who asserts that affordances are ecological per se. He defines affordances as things that furnish or afford the observer. In this view, Ziglari (2008) refers to two types of affordances: natural and cultural. The example of natural affordances is the case of a flat hard surface which is walkable-on for the human beings. Cultural artifacts, or manufactured objects, in contrast, are examples of cultural affordances whose intended use signals their purpose. Nevertheless, the ecological perspective - its use in the classroom, and its relationship with interaction - is later manifested in the work of van Lier (2010).

Van Lier explains ecology of language learning from practice to theory and vice versa. Van Lier argues the aim of ecological approach is "to look at the learning process, the actions and activities of teachers and learners, [and] the multilayered nature of interaction and language use" (p. 3). Elsewhere, van Lier (1996) claims that ecological perspectives place emphasis on both the social interaction that makes linguistic affordances available to the learner and also the cultural context where language learning occurs.

Van Lier (2000) also proposes that the input-output model should be replaced by an ecological perspective. According to van Lier, an ecological approach takes into consideration what is taking place in the environment. Van Lier's contention is also echoed by Kramsch (2002) who considers an ecological approach to language learning a powerful way of capturing the mutualistic relationship between the language users and the environment. Accordingly, it is plausible to say that nobody learns alone; the same way nobody grows up, lives, suffers, or dies alone. However, what springs to our mind is that how second language learners in a poor linguistic environment can learn a new language. In effect, from an ecological perspective, we can claim that too little resources will result in death or very minimal growth. Along the same vein, we can also predict that learning a language in poor environments, with lack of input and interaction, will also lead to minimal evolution.

Van Lier (2000), in support of the ecological approach, uses the term affordance for input and argues that the 
environment makes available opportunities for learners to engage in meaning-making activities with others (a semiotic budget), and what is perceived relevant and acted upon by the learner becomes an affordance. In other words, input has been reconceptualized as the linguistic affordances perceived and used by the learner for linguistic action. Input is, therefore, not something standing outside the learner waiting to be acquired, but it is the interaction between the learner and the environment. Henceforth, emergence, together with affordance, is among the two fundamental concepts in the ecological approach that is in close contact with the notion of interaction. Affordance means that ecology of language learning is formed in terms of the relations between people and the world that provides opportunities and inhibitions of action. Emergence is also based on the theme that the properties of a complex system are emerged out of a simple set of mechanisms (Ellis, 1998). Similarly, emergentists place emphasis on the interaction between organism and environment and reject the notion of predetermined capacity (Ziglari, 2008).

Regarding the relativity of affordance to the realness of language learning and teaching, Gibson (1971) holds that affordance is not an ecological feature rather than a phenomenological feature of objects. As human beings are unique, not all individuals perceive their environment in the same way. Thus, it is a necessity on the part of teachers in class to become aware of students' needs to provide a rich environment and suitable materials. As Ziglari (2008) states, learners can perceive some aspect of these materials that fit into their knowledge and accordingly try to interact with their environment. Put another way, if the meaning of affordance is not clear and misinterpreted by the students, there will be a mismatch between the teacher and students, and, consequently, this would result in inhibition in the process of learning.

Using ecological perspectives in teaching different skills can also be beneficial. In this regard, Fahim and Sabah (2012) did an ecological analysis of the part that role-play games play in the degree of vocabulary learning and recall. The study shows that the subjects drawing on their prior knowledge reveal background information about the content, and strive to take part in communicative interactions. Furthermore, games compatible with the affordance features are observed to help the students gain agency in accomplishing the gaming activities.

\section{Dialectical Interaction}

Besides ecological approach that keeps the role of interaction in SLA to maximum, Bakhtin's (1981) dialogized heteraglossia appears to move on the same line. Bakhtin objecting strenuously to the view of language as langue, as a system of abstract norms, holds that the language we assimilate comes to us already dialogized, already spoken out. In Saussurean view, as Hall, Vitanova, and Marchenkova (2005) assert language consists of a set of fixed structures and rules that can be studied in a decontextualized fashion. In response to the traditional approach, Bakhtin (1981) has developed a new idea in which language is made up of dynamic socio-cultural sources that are in constant relation with their social and historical context. In sum, Bakhtin's dialogic approach is classified as poststructuralist. Poststructuralist theories are in contrast with structuralist theories of language associated with the work of Saussure's (1959 cited in Norton \& McKinney, 2011) distinction between parole and langue. For Saussure, the building blocks of language are comprised of the signifier (signs) and the signified (mental concept). Saussure asserts that neither the signifier nor the signified preexists, and that the link between them is conventional. In contrast, poststructuralists argue that structuralism cannot account for struggles over the social meanings that can be attributed to signs within a given language (Norton \& McKinney, 2011). In other words, poststructuralists claim that one cannot claim a meaning that can be attributed to signs in a given language. The meaning of woman, for instance, is not intrinsic but is given from its difference from other signs, such as man or female. In fact, for structuralists, signs are conceived as having idealized meanings and communities as being relatively homogeneous. Saussure's principle, therefore, is that meaning is produced within language not reflected by language. In contrast, poststructuralists claim that linguistic communities, as being heterogeneous, are sites of struggle in seek for truths and power.

Hall et al. (2005), outlining the important terms of Bakhtin's (1981) poststructuralist approach, maintain that the first concept is utterance defined as concrete response to the conditions of the moment. To Bakhtin, utterances have different forms called speech genres. Since in every utterance the history and present comes together, Bakhtin used the term "dialogic" for this dynamic interaction which shapes individual voices. Furthermore, these utterances are historically contingent; that is, they are positioned within and are inseparable from community. Accordingly, Hall et al. declare that such a view eliminates "any a priori distinction between form and function and between individual and social uses of language" (p. 3).

In this regard, Jordon (2004) asserts that the speech genres that Bakhtin (1981) refers to include two forces that work simultaneously. One force leads to the unification and centralization of language named as centripetal. This unity is the sameness of everyday conversations. Centrifugal, the other force, makes speech diverse, 
heterogeneous and varied. Jordan goes on to hold that that Bakhtin has proposed his dialogized heteroglossia based on the force, centrifugal, which is more powerful than centripetal force. In the same line, self is represented in a dynamic process mediated by speech in dialogue form in order to merge internal and external forces (inner and outer world).

Another important notion in Bakhtin's dialogic hetereglossia is the concept of context. There is not an agreed-upon definition of context. Unlike positivists who see contexts stable and independent of the actions of individuals, Bakhtin's approach inclines towards phenomenology. From a phenomenological lens, Dourish (2004) states, "contextuality is a relational property" (p. 4). To Dourish, contextuality results in when it is mutually recognized by the parties involved in interaction. In fact, "context isn't something that describes a setting; it's something that people do" (p. 6). Henceforth, regarding the importance of context, Bakhtin (1981) asserts that understanding linguistic forms out of context and considering utterances without context as purely individual act is unattainable. Akhutina (2003) also declares, "the possibility of understanding words (speech) rests on the fact that the people conversing share a context" (p. 98).

According to Bakhtin (1981), language lies on the border between oneself and the other. What Bakhtin calls as dialogism connotes mutual participation of speakers and hearers in the construction of utterances and the connectedness of all utterances to past and future expressions. Bakhtin views the use of language as an appropriation of words that at one time existed in other people's mouths before they are made. As Hall (2002, cited in Zungler \& Miller, 2006) claims, in such a view, an utterance can be understood fully by considering its history of use by other people, in other places for other reasons.

Bakhtin's (1981) dialogic approach and also Vygotsky's (1962) socio-cultural perspective help us to merge two opposite parts of mental and social aspects in human beings for a holistic and dialectical view in second language learning (Johnson, 2004). Based on the dialogic principles deduced from Vygotsky's socio-cultural theory and Bakhtin's dialogic heteroglossia, Johnson concludes that in a dialectical relationship language is not universal but localized; language performance and competence are not separable; cognition and second language development are not separated, rather one transforms the other.

In sum, to Bakhtin $(1981,1986)$ language is not seen as a set of idealized forms independent of their speakers or their speaking, but rather as situated utterances in which speakers are in struggle with others to create meanings. For Bakhtin, the notion of individual speaker is a fiction because utterances are constructed jointly. He steadfastly pursues the idea that language development is a matter of appropriating the words of others. Speakers need to struggle to appropriate the voices of others and to bend those to their own purposes.

Moreover, Bakhtin's heteroglossia is also inspired by the philosophy of idealism. One of the implications of this philosophical stream in education is that theory must precede practice, and therefore, texts alone are not sufficient because the letter of the text is always subject to misinterpretation. Henceforth, for the text to be understood, the spirit of the text must be discerned. Accordingly, Bakhtin (1984, cited in Yuksel, 2009) argues that idealism stresses only one type of interaction where someone who has the truth (knowledge) passes it on to the person who is in lack of it. Bakhtin criticizing the idealistic conception of knowledge goes on to hold that "truth is not born nor [is it] found inside the head of an individual person, [but] it is born between people collectively searching for truth, in the process of their dialogic interaction" (cited in Yuksel, 2009, p. 3). Henceforth, truth and knowledge are made as a dialogic interaction of different elements. In other words, to Bakhtin, as to Norton and Toohey (2002), language and the speaker of the language are surrounded by different ecological factors which affect their interaction with others and make a struggle for speaker to create meaning. Thus, Bakhtin's approach is ecological rather than phenomenal since it is concerned with the study of the interrelationship between an organism and its environment.

\section{Pedagogical Implications of Interaction in the Classrooms}

In case learners are competent in a language, they will be able to communicate with dynamic and heterogeneous speech genres of that language in which native speakers show varying degrees of competence. Acquiring these genres is not possible unless careful modeling, guided rehearsal, and feedback regarding their performance are provided and considered in their pedagogy (Bakhtin, 1986). Henceforth, bringing Bakhtin's view to the field of SLA, Hall et al. (2005) suggest some crucial implications. First, seeing language as a living tool which is dynamically structured and emerged helps us make, keep, and shape our cultural world for our own purposes. Second, learning, based on the tenets of emergentism, is respected as the product of a social interaction rather than a process which happens in individuals' mind.

Following Bakhtin's approach, Johnson (2004) has also proposed that classroom setting requires authentic social context, and not the artificial one that does not resemble the outside realities. Each student needs to have a zone 
of proximal development through which, with the help of dialogized interaction, uses different genres and voices and also co-constructs his or her self and cognitive development. In such a situation, as Swain (2000) mentions, interaction can have different forms. It can be in the format of collaborative dialogue that language use and learning co-occur or the former mediates the latter. It can also be in the forms of cognitive and social activities, or, according to van Lier (1996), it can be in the form of every day conversation.

Johnson (2001 cited in Johnson, 2004) also considers the unplanned nature of conversation and unpredictability of outcomes among the features of conversation. These features lead van Lier (1996) to think of conversation as the best form of interaction to improve learners' autonomy as the prerequisite of higher mental functioning, power, and reaching the self-regulated stage from the other-regulated stage. Still, knowledge and skills acquired in interactive classroom activities within individualized zone of proximal development should be relevant to the L2 learners' particular needs and goals outside the classroom.

Moreover, it might be beyond the capacity of schools to provide the necessary affordances for SLA. Henceforth, as Ziglari (2008) puts forth, "it is better for the teacher to expose the learners to the real and natural settings so that they could perceive their world much better and increase their world knowledge" (p. 378). Along the same vein, van Lier (2000) asserts that "perhaps, after all, we 'learn' language in the same way that an animal 'learns' the forest, or a plant 'learns' the soil" (p. 259).

\section{Conclusion}

As Firth and Wagner (1998) note, "language is acquired and learned through social interaction and should be studied in interactive encounters" (p. 287). In the same line, Kumaravadivelu (2006) asserts that language is not simply a network of interconnected linguistic systems; rather, it is a web of interlinked sociopolitical and historical factors that shape one's identity and voice. Moreover, from a critical theory perspective, the utterance we produce as the momentous concept in dialogic heteroglassia reveals our stance towards the interlocutors, signaling our social positioning within the local interaction and in response to larger sociopolitical forces. In this case, the role of social power can be understood in the social world.

Concentrating on Bakhtin's dialogic approach, we claim that all learning is context-dependent. Philosophically speaking, Bakhtin (1984, cited in Norton \& McKinney, 2011) states that languages are situated utterances in which meaning is created in the dialogue between speakers. In such a view, words are not neutral; they bear the value and express the predispositions. Struggling to appropriate others' voices and use them as one's own is among Bakhtin's ideology which is not only linguistic but social endeavor. Henceforth, to appropriate others' voices, learners need to have interaction, yet having interaction with others does not end in reducing the significance of innateness. Inspired by Lust (2006) who maintains that learning and innateness are not contradictory, but complementary, we can claim that disentangling the impact of nurture and nature on SLA is impoverished since genetic predispositions and environmentally dependent learning processes act continuously at every neural and mental entity (Gunturkun, 2006).

We are blind without nurture (Güntürkün, 2006) in general, and interaction in particular. We certainly go on shaping our brain and culture through interactions. As Anton (1999) puts, in-class interaction, for instance, increases the opportunities of scaffolding as a facilitating mechanism to cognitive development and social development. Thus, the scaffolding derived from an expert is as necessary as the collaboration among a group of peers. Even more, interaction between a pair of L2 learners at the same cognitive level can provide the appropriate scaffolding needed for L2 cognitive development (Swain \& Lapkin 1998). In effect, interaction as an interpersonal activity refers to learner-learner (or nonnative-nonnative) interaction. Seen from socio-cultural perspective, language is the product of interaction; essentially, we are inheritably destined to interact with others to gratify our needs (Shakouri-Masouleh \& Bahraminezhad-Jooneghani, 2012). In a sense, classrooms cannot be divided by a sharp line, but everyone has a small part of himself or herself in it. If the role of individuals is legitimized in the class, the exercise of power will be determined by thousands of interactions. Still, it is undeniable to claim that SLA is mediated by gene-environment, nature-nurture interaction. Similarly, Fausto-Sterling (2004) declares, "if we think about nature and nurture as each being $100 \%$, organisms are $100 \%$ nature and 100\% nurture" (p. 81).

\section{References}

Akhutina, T. V. (2003). The theory of verbal communication in the works of M. M. Bakhtin and L. S. Vygotsky. Journal of Russian and East European Psychology, 41(3), 96-114.

Anton, M. (1999) The discourse of a learner-centered classroom: Sociocultural perspectives on teacher-learner interaction in the second-language classroom. The Modern Language Journal, 83(3), 302-318. 
Bakhtin, M. M. (1981). The dialogic imagination. (C. Emerson, \& M. Holquist, trans.). Austin: University of Texas Press.

Bakhtin, M. M. (1986). Speech genres and other late essays (V. W. McGee, trans.). Austin: University of Texas Press.

Dourish, P. (2004). What we talk about when we talk about context. Pers Ubiquit Comput, 8, 19-30. http://dx.doi.org/10.1007/s 00779-003-0253-8

Ellis, N. (1998). Emergentism, connectionism, and language learning. Language Learning, 48(4), 631-664. http://dx.doi.org/10.1111/0023-8333.00063

Ellis, R. (1999). Learning a second language through interaction. Amsterdam: John Benjamins Publishing.

Fahim, M., \& Sabah, S. (2012). An ecological analysis of the role of role-play games as affordances in Iranian EFL pre-university students' vocabulary learning. Theory and Practice in Language Studies, 2(6), 1276-1284.

Fausto-Sterling, A. (2004). Commentatory. In C. G. Coll, E. L. Bearer, \& R. M. Lerner (Eds.), Nature and nurture: The complex interplay of genetic and environmental inferences on human behavior and development (pp. 79-84). New Jersey: Lawrence Erlbaum Associates, Publishers.

Firth, A., \& Wagner, J. (1998). SLA property: No trespassing. The Modern Language Journal, 82(1), 91-94. http://dx.doi.org/10.1111/j.1540-4781

Gibson, J. J. (1979). A preliminary description and classification of affordances. Retrieved in 2013 from www.huwi.org/gibson/prelim/php

Güntürkün, O. (2006). Letters on nature and nurture. In P. B. Baltes, P. A. Reuter-Lorenz, \& F. Rösler (Eds.), Lifespan development and the brain: The perspective of biocultural co-constructivism (pp. 379-397). Cambridge: Cambridge University Press.

Hall, J. K., Vitanova, G., \& Marchenkova, L. (2005). Dialogue with Bakhtin on second and foreign language learning. Mahwah: Lawrence Erlbaum Associates, Inc.

Halliday, M. A. K. (1994). An introduction to functional grammar (2nd Ed.). London: Edward Arnold.

Johnson, M. (2004). A philosophy of second language acquisition. Boston: Yale University.

Jordan, G. (2004). Theory construction in second language acquisition. Amsterdam: John Benjamins Publishing Company.

Krashen, S. D. (1981). Second language acquisition and second language learning. Oxford: Pergamon.

Kramsch, C. (2002). Introduction: "How can we tell the dancer from the dance?" In C. Kramsch (Ed.), Language acquisition and language socialization: Ecological perspectives (pp. 1-30). New York: Continuum International Publishing Group.

Kumaravadivelu, B. (2006). Understanding language teaching: From method to postmethod. New Jersey: Lawrence Erlbaum Associates.

Larsen, Freeman, D. (1991). Second language acquisition research: Staking out the territory. TESOL QUARTERLY, 25 (2), 315-350. http://dx.doi.org/10.2307/3587466

Lightbown, P. M., \& Spada, N. (1999). How languages are learned. Oxford: Oxford University Press.

Long, M. H. (1981). Input, interaction and second-language acquisition. In H. Winitz (Ed.), Native language and foreign language acquisition: Vol. 379. Annals of the New York Academy of Sciences (pp. 259-278). New York: New York Academy of Sciences.

Lust, B. C. (2006). Language acquisition: Acquisition and growth. Cambridge: Cambridge University Press.

Mackey, A. (1999). Input, interaction and second language development: An empirical study of question formation in ESL. Studies in Second Language Acquisition, 21, 557-587.

Newman, D., Griffin, P., \& Cole, M. (1989). The construction zone: Working for cognitive change in school. Cambridge: Cambridge University Press.

Norton, B., \& McKinney, C. (2011). An identity approach to second language acquisition. In D. Atkinson (Ed.), Alternative approaches to second language acquisition (pp. 73-94). New York: Routledge.

Norton, B., \& Toohey, K. (2002). Identity and language learning. In R. Kaplan (Ed.), Handbook of applied 
linguistics (pp. 115-123). Oxford: Oxford University Press.

Pienemann, M. (1998). Language processing and second language development: Processability theory. Amsterdam: John Benjamins.

Shakouri-Masouleh, N., \& Bahraminezhad-Jooneghani, R. (2012). SLA: Concept of context in community. Theory and practice in language studies, 2(5), 1003-1007.

Swain, M. (1995). Three functions of output in second language learning. In. G. Cook, \& G. Seidhofer (Eds.), Principles and practices in applied linguistics: Studies in honour of H. G. Widdowson (pp. 125-144). Oxford: Oxford University Press.

Swain, M. (2000). The output hypothesis and beyond: Mediating acquisition through collaborative dialogue. In J. P. Lantolf (Ed.), Sociocultural theory and second language learning (pp. 97-114). Oxford: Oxford University Press.

Swain, M., \& Lapkin, S. (1998). Interaction and second language learning: Two adolescent French immersion students working together. The Modern Language Journal, 82(2), 320-337.

Van Lier, L. (1996). Interaction in the language curriculum: Awareness, autonomy, and authenticity. London: Longman.

Van Lier, L. (2000). From input to affordance: Social interactive learning from an ecological perspective. In J. P. Lantolf (Ed.), Sociocultural theory and second language learning: Recent advances (pp. 245-259). Oxford: Oxford University Press.

Van Lier, L. (2010). The ecology of language learning: Practice to theory, theory to practice. Procedia Social and Behavioral Sciences, 3, 2-6. http://dx.doi.org/10.1016/j.sbspro. 2010.07.005

VanPatten, B. (2004). Input and output in establishing form-meaning connections. In B. VanPatten, J. Williams, S. Rott, \& M. Overstreet (Eds.), Form-meaning connections in second language acquisition (pp. 29-48). New Jersey: Lawrence Erlbaum Associates.

Vološino, V. N. (1986). Marxism and the philosophy of language (L. Matejka, \& I. R. Titunik, tran). Cambridge: Harvard University Press.

Vygotsky, L. (1962). Thought and language. Cambridge, MA: MIT Press.

Yazan, B. (2012). Divergent philosophical orientation underpinning SLA research. Working Papers in Educational Linguistics, 27(1), 1-18.

Yuksel, D. (2009). A Bakhtinian understanding of social constructivism in language teaching. Journal of language and linguistic studies, 5(91), 1-19.

Ziglari, L. (2008). Affordance and second language acquisition. European Journal of Scientific Research, 23, (3), 373-379.

Zungler, J., \& Miller, E. R. (2006). Cognitive and sociocultural perspectives: Two parallel SLA worlds. TESOL Quarterly, 40(1), 35-58.

\section{Copyrights}

Copyright for this article is retained by the author(s), with first publication rights granted to the journal.

This is an open-access article distributed under the terms and conditions of the Creative Commons Attribution license (http://creativecommons.org/licenses/by/3.0/). 